NBER WORKING PAPER SERIES

\title{
DO INCREASING MARKUPS MATTER? LESSONS FROM EMPIRICAL INDUSTRIAL ORGANIZATION
}

\author{
Steven T. Berry \\ Martin Gaynor \\ Fiona Scott Morton \\ Working Paper 26007 \\ http://www.nber.org/papers/w26007 \\ NATIONAL BUREAU OF ECONOMIC RESEARCH \\ 1050 Massachusetts Avenue \\ Cambridge, MA 02138 \\ June 2019
}

We wish to thank Al Klevorick and editors at the Journal of Economics Perspectives-Enrico Moretti, Gordon Hanson, and managing editor Tim Taylor-for helpful comments and suggestions that substantially improved the paper. The usual caveat applies. The views expressed herein are those of the authors and do not necessarily reflect the views of the National Bureau of Economic Research.

At least one co-author has disclosed a financial relationship of potential relevance for this research. Further information is available online at http://www.nber.org/papers/w26007.ack

NBER working papers are circulated for discussion and comment purposes. They have not been peer-reviewed or been subject to the review by the NBER Board of Directors that accompanies official NBER publications.

(C) 2019 by Steven T. Berry, Martin Gaynor, and Fiona Scott Morton. All rights reserved. Short sections of text, not to exceed two paragraphs, may be quoted without explicit permission provided that full credit, including $\odot$ notice, is given to the source. 
Do Increasing Markups Matter? Lessons from Empirical Industrial Organization

Steven T. Berry, Martin Gaynor, and Fiona Scott Morton

NBER Working Paper No. 26007

June 2019

JEL No. L0,L1,L4

\begin{abstract}
$\underline{\text { ABSTRACT }}$
This paper considers the recent literature on firm markups in light of both new and classic work in the field of Industrial Organization. We detail the shortcomings of papers that rely on discredited approaches from the "structure-conduct-performance" literature. In contrast, papers based on production function estimation have made useful progress in measuring broad trends in markups. However, industries are so heterogeneous that careful industry specific studies are also required, and sorely needed. Examples of such studies illustrate differing explanations for rising markups, including endogenous increases in fixed cost associated with lower marginal costs. In some industries there is evidence of price increases driven by mergers. To fully understand markups, we must eventually recover the key economic primitives of demand, marginal cost, and fixed and sunk costs. We end by discussing the various aspects of antitrust enforcement that may be of increasing importance regardless of the cause of increased markups.
\end{abstract}

Steven T. Berry

Department of Economics

Yale University

Box 208264

37 Hillhouse Avenue

New Haven, CT 06520-8264

and NBER

steven.berry@yale.edu

Martin Gaynor

Heinz College

Carnegie Mellon University

5000 Forbes Avenue

Pittsburgh, PA 15213-3890

and NBER

mgaynor@cmu.edu
Fiona Scott Morton

Yale School of Management

Box 208200

New Haven, CT 06520-8200

and NBER

fiona.scottmorton@yale.edu 
Many economists and policymakers are expressing concern over the possibility of increasing monopoly power in the US and the world economy. There have been decades of research in industrial organization devoted to understanding how one can (and cannot) reliably learn about the causes and consequences of market power and markups-that is, a positive difference between price and marginal cost.

Starting about 30 years ago (Bresnahan 1989), the field of industrial organization adopted methods for understanding firm conduct and markets based on the relevant economic primitives: demand, cost, and pricing conduct. Thus, under the assumptions that firms maximize profits and have to cover their total costs, the equilibrium price (and other outcomes such as product choice, location, quality, innovation) will be determined by demand, marginal costs and fixed (possibly sunk) costs, along with the conditions of competition that shape pricing behavior. These conditions are modeled using modern game theory to incorporate imperfect competition, product differentiation, multiproduct firms and firm entry, as well as a host of industry-specific institutions.

However, a number of recent studies of markups instead employ an analytical approach that was broadly rejected by the field of industrial organization more than 30 years ago: the structure-conduct-performance paradigm. We begin by discussing the shortcomings of this approach, which involves regressions with an outcome like markups or profits on the left-hand side, and a measure of market concentration on the right-hand side, along with various control variables. This approach faces severe measurement problems, and worse conceptual problems. As we will explain, there are a number of quite different economic scenarios, with different welfare implications, which can result in a positive correlation between industry concentration and markups.

We then turn to some research that avoids the problems of the structure-conduct-performance approach. Although we mention several approaches, our main focus will be on recent studies taking an industrial organization approach. As we will see, studies built on economic primitives sometimes describe a situation in which large firms are changing products and production methods, including the mix of marginal and fixed costs, over time. In some cases, the welfare effects for consumers are ambiguous; in others, larger firms seem to raise markups without a corresponding consumer benefit. In some of these cases, mergers may be playing a role in increasing markups. The strength of these industry-level studies is that they offer detailed insights into causes of higher markups; the corresponding downside is that without a surge of additional studies, it can be difficult to draw inferences about overall levels and trends in markups across the economy.

Building on these industrial organization studies, we summarize some of the main possible causes of expanding markups rooted in the underlying economic primitives. Possibilities include a rise in fixed or sunk costs, network effects, monopsony effects in labor markets, an increase in rent-seeking behavior, and global effects. As an example, higher fixed (and/or sunk) costs can 
lead to fewer firms in a market, which can result in softer competition, higher prices and reduced consumer welfare. On the other hand, in some cases higher fixed/sunk costs can be the endogenous outcome of improved products or of improved production technology that lowers marginal cost (Sutton 1991). In this case, observed higher markups may or may not be associated with higher prices and reduced consumer welfare.

In the final section of the paper, we turn to antitrust enforcement and competition policy, both because weakened antitrust policy offers a potential explanation for rising markups, but also because even if the main explanations lie elsewhere, antitrust policy offers some policy levers to address the rise in markups. Given the uncertainties about the size of the rise and rise in markups, and that these seem likely to vary across industries, we argue that policy makers should consider policies that are beneficial under a wide range of conditions, for example, assuring that market entry is not blocked, that dominant incumbent firms don't engage in conduct to disadvantage rivals and harm competition, and that anticompetitive conduct in labor markets is not permitted. We also offer the important caveat that regulatory, trade, and tax policies may also prove important in addressing any harms associated with increased markups.

\section{Problems with Some Recent Studies of Market Power}

Early empirical research in industrial organization from the 1950s into the 1970 s employed the "structure-conduct-performance" paradigm to study how the extent of competition affected on market outcomes. This empirical implementation of the paradigm typically involved regression analysis. The dependent variable was a market outcome like profits, markups or prices. The key explanatory variable seeks to capture the structure of the market with a measure of a measure of concentration-usually the Herfindahl-Hirschman Index ( $\mathrm{HHI})$, which is the sum of squared market shares. The regression also included a range of control variables intended to capture other exogenous reasons for variation. Structure is thus related to performance, with (unobservable) conduct captured as the estimated relationship between structure and performance. In this regression, the coefficient on the concentration measure is intended to capture how the toughness of competition changes as market concentration changes.

Within the field of industrial organization, the structure-conduct-performance approach has been discredited for a long time (Bresnahan 1989; Schmalensee 1989). But outside of industrial organization, the paradigm seems to have been readopted in recent years. Much of the recent attention to increasing markups or other market outcomes focuses on exactly this kind of evidence (for example, Furman 2015; Azar, Marinescu, and Steinbaum 2017; Barkai 2017; Bessen 2017; Gutiérrez and Philippon 2017a, b; Smith 2017; Azar et al. 2018; Benmelech, Bergman, and Kim 2018; Furman and Orszag 2018; Grullon, Larkin, and Michaely forthcoming). Such work sometimes proceeds without addressing the problems that led the field of industrial organization to reject the structure-conduct-performance approach. 
Given the intuitive relationship between market concentration and firm performance, why did industrial organization reject the structure-conduct-performance paradigm? Researchers using the structure-conduct-performance approach were well aware of the limits of their approach at the time, as emphasized by Schmalensee (1989). We start with a discussion of measurement problems. The most important point, though, is that there are multiple causal paths that can explain a given correlation between concentration and other market outcomes. This implies that the very question--"what is the effect of concentration on prices or markups?" -is not well-posed.

Measuring concentration is inherently difficult, because economic markets are not observed directly in the data. For example, industrial classifications in the Census often fail to reflect welldefined economic markets. It is fairly clear that that "software" is not a single industry, but much less clear how to divide it into separate industries. Other problems arise from geography. If Census data in an industry shows a large number of small firms, this may represent a situation where they are in direct competition with each other or else they may actually operate in quite separate geographic or product markets. The Census does not measure degrees of product differentiation or homogeneity, or any measures of product-level prices.

Measuring economic outcomes was another problem for research in the structure-conductperformance tradition. Most measures of profits use accounting measures, which are not economic profits. Markups are rarely directly observed in firm-level data at all, in part because firms' accounting structures are not set up to measure the economic concept of product-level marginal cost (Fisher and McGowan 1983). Attempts to estimate marginal cost involved additional difficult measurement problems with regard to the size fixed costs, sunk costs, and depreciation. In a best-case scenario, measured markups involve the markup of price over average variable cost.

Some researchers in the structure-conduct-performance tradition came to regressions using price as the dependent variable, rather than accounting profits or markups. But then, comparing prices across industries then led to a call for industry-level structure-conductperformance studies (Weiss 1990). Researchers understood that the nature of competition differs substantially from one industry to the next. For example, prices are determined in the food distribution industry via second price auction, in health care via bilateral bargaining, and in retail as posted prices. As a consequence of the deep differences between industries, it's unclear what sorts of inferences are possible from estimates that aggregate across industries with such fundamental differences.

But even if the structure and output variables were measured with precision, and the analysis was within a single industry, structure-conduct-performance researchers beginning with Demsetz (1973) often grappled with the problem of interpreting their regressions. For example, Ravenscraft (1983) regressed firm-level markups on firm market share and industry concentration, finding a coefficient on market share that was positive and significantly different from zero, but a near zero (or even negative) coefficient on industry concentration. Still, it was hard to give any definitive interpretation to such regressions. Imagine that large firms have high 
fixed costs and low marginal costs, and low marginal costs are associated with higher markups (in part because the price needs to recover the high fixed costs). This can create a correlation between firm size or the Herfindahl-Hirschman Index for an industry and markups.

One way of approaching the Demsetz (1973) empirical critique is that concentration is econometrically endogenous, suggesting a search for possible instruments. However, in many cases it is not at all clear what variables are excluded from the "concentration-markup" regression, which naturally depends on all elements of demand and marginal cost.

However, the critique runs deeper than concerns over endogeneity. Different changes in primitives, with very different positive and normative implications, can produce the same observed correlations between concentration and markups. Demsetz (1973) emphasized the path from improved marginal cost to the joint outcome of concentration and measured accounting markups. This path can exist even in a model of perfect competition with heterogeneous upward sloping marginal cost curves. In contrast, the original structure-conductperformance researchers emphasized the path from exogenous mergers to the joint outcome of high concentration and higher prices and reduced consumer welfare, which offers an equally coherent story. One can also tell a story in a differentiated products context, in which a reduction in search or trade costs may shift market share towards firms with high quality products, increasing both concentration and consumer welfare (as emphasized in Autor et al. 2017).

In short, there is no well-defined "causal effect of concentration on price," but rather a set of hypotheses that can explain observed correlations of the joint outcomes of price, measured markups, market share, and concentration. ${ }^{1}$ As Bresnahan (1989) argued three decades ago, no clear interpretation of the impact of concentration is possible without a clear focus on equilibrium oligopoly demand and "supply," where supply includes the list of the marginal cost functions of the firms and the nature of oligopoly competition.

Some of the recent literature on concentration, profits, and markups has simply reasserted the relevance of the old-style structure-conduct-performance correlations. For economists trained in subfields outside industrial organization, such correlations can be attractive. Our own view,

\footnotetext{
${ }^{1}$ As a more specific example, in the Cournot model, the Lerner Index of price-cost markups is equal to the Herfindahl-Hirschman Index divided by the absolute value of the market demand elasticity (Cowling and Waterson 1976). If we could somehow empirically identify an industryspecific coefficient on the Herfindahl in a regression of the correctly measured Lerner Index on concentration, we would learn only one demand parameter, not nearly enough to know (for example) how a merger would affect industry markups. Even within the Cournot model, reductions in marginal cost will produce one kind of joint effect on the Herfindahl index and markups, whereas a merger will produce an altogether different set of joint effects (Farrell and Shapiro 1990). Most industries are, of course, not well-approximated by the Cournot model and extracting causal predictions from those industries is even harder.
} 
based on the well-established mainstream wisdom in the field of industrial organization for several decades, is that regressions of market outcomes on measures of industry structure like the Herfindahl-Hirschman Index should be given little weight in policy debates. Such correlations will not produce information about the causal estimates that policy demands. It is these causal relationships that will help us understand what, if anything, may be causing markups to rise.

\section{Detailed Industry Studies of Market Power}

What kind of studies might provide better-grounded evidence on the underlying causes of shifts in concentration or mark-ups?

As a starting point, we might seek to establish a descriptive baseline for analysis, without jumping to causal statements. Is concentration in general rising across many firms and industries or a relatively small number? Are accounting markups rising? Are prices rising? What are the descriptive correlations across these variables? The answers to these questions can often point to fruitful areas for detailed study as well as rule out concerns that are unsupported by the facts. We can then consider approaches to interpreting these fact patterns that may lead us to firmer policy conclusions.

As an example, Ganapati (2018a) builds on and extends recent work to address some of these correlational issues. In common with other papers, he finds a rising economy-wide trend toward increased concentration. Using industry-level price indices, in a difference-in-difference analysis he finds that "concentration increases are positively correlated to productivity and real output growth, uncorrelated with price changes and overall payroll, and negatively correlated with labor's revenue share." Autor et al. (2017) use firm-level panel data to document that the increase in concentration is largely due to reallocation of market share toward the pre-existing set of large and productive firms. This change is associated with a decrease in the labor share. Autor et al. provide a model that attributes these correlations to the rise of "superstar" productive firms. Although a number of authors report findings of increasing concentration across a wide range of industries, this finding is not universal. For example, Rossi-Hansberg, Sarte, and Trachter (2019) find falling concentration in local product markets, in part because entry of national firms will increase competition in local markets.

In an alternative approach, there has been a recent wave of "production function" approaches to measuring mark-ups. These studies often use data from the financial accounts of firms to estimate firm-level production functions, which in turn serve as a basis to estimate the size of mark-ups. One advantage of this approach is that it directly addresses the issue of markups in the economy as a whole. Another advantage is that these papers do not use measures of industry concentration, and thus not suffer from the fundamental methodological flaws of papers that use the structure-conduct-performance paradigm. However, a corresponding disadvantage of broad-based approaches to estimating markups using financial accounting data or aggregate data is that modeling and estimation approaches that fail to model industry 
specific characteristics restrict the range of answers that we can learn from data. We believe that this research provides persuasive evidence that markups have been rising, although open questions remain about the magnitude and causes of the effect. In this symposium, the papers by Basu and by Syverson discuss this approach in detail. ${ }^{2}$

However, the main focus of this paper is to discuss what we can conclude from industry-specific studies about the sizes and causes of markups and therefore what policy responses would be appropriate. In these industry-level studies it may be plausible to identify markups from data on prices and output, together with data on demand and cost shifters and some industry appropriate assumptions on competitive behavior. Detailed industry studies can provide direct evidence on the causes and consequences of imperfect competition. The relatively narrow focus of industry specific studies may frustrate economists who are accustomed to working with all firms in one model and dataset, as is often the case in macro and finance. But the nature of demand, costs, and competitive setting that affect firm choices are inherently heterogeneous.

Here, we do not try to review the vast literature in this area, but instead focus on a few recent studies which illustrate some contexts in which this research is done, and how the welfare implications of such research can be ambiguous, combining elements of lower cost, improved quality, and decreased competition.

As a first example, Ganapati (2018b) studies the large wholesaling sector of the economy. Ganapati notes that, in 2012, wholesalers accounted for 50 percent of sales to downstream buyers in the US manufactured goods market and that, contrary to prominent examples of large retailers disintermediating wholesalers, the wholesale sector overall is growing in size. As the wholesale sector has grown, it has become more concentrated, and accounting markups have increased. This has happened largely due to increases in the market shares of the largest wholesalers. This increase in concentration has been accompanied by increased spending on information technology, by the opening of warehouses closer to consumers, and by increased dual sourcing from domestic and foreign sources. Purely from the descriptive data, this story

\footnotetext{
2 Prominent examples of this production function approach with US data include De Loecker and Eeckhout (2017, 2018), Hall (2018), and Eggertsson, Robbins, and Wold (2018). For example, De Loecker and Eeckhout (2017) in their primary analysis use firm-level financial statements from Compustat, including measures of sales, spending on inputs, capital stock, and industry classifications. Studies using this general approach international data include De Loecker and Eeckhout (2018) and Calligaris, Criscuolo and Marcolin (2018). All of these papers find evidence of positive and rising markups. These studies are not just rising markups overall, but the fact that the rise in markups is due to a small number of firms. Again, for additional details, see the papers by Basu and by Syverson in this symposium. For other careful discussions, see also Yurukoglu (2018) and Raval (2019), as well as De Loecker and Eeckhout (2018b) for a response to criticisms.
} 
seems more complicated than either "perfect competition" or a classic Cournot-style oligopoly story of increased homogeneous goods concentration leading to higher prices and reduced output.

To interpret these trends, Ganapati (2018a) applies a series of standard empirical industrial organization models of demand, pricing, and entry. These models are fit to detailed US Census data, with identification coming from "supply and demand"-style instrumental variable methods (Berry and Haile 2014). In particular, he uses data on the number of wholesalers by type and location, on market size, and on shifters of marginal cost. Ganapati concludes that the growth in the wholesale sector is driven by a combination of lower marginal costs and increased demand, which is in turn driven by an improved warehouse network as well as improved sourcing quality from both domestic and foreign locations.

The benefits of these improvements for downstream customers are constrained by lessened competition that yields an increase in markups over marginal cost. In Ganapati's (2018a) entry model, the improved product quality and lower marginal costs are associated with higher fixed costs that are created by the firm's location, quality, and sourcing decisions (similar to the "endogenous fixed cost" models of Sutton 1991). However, Ganapati does not attempt to attribute these fixed costs to any specific source. They could be the information technology costs of improved logistics or the sunk costs of building out a warehouse structure. Alternatively, they could represent a rent due to oligopolistic behavior and (perhaps) firstmover advantages in establishing wholesale networks. The findings indicate that in this sector, while concentration and markups are rising, quality is rising and costs are falling, thus leading to a setting that is not easy to evaluate. Research on a number of other prominent industries finds patterns with similarly ambiguous welfare implications.

Note that, unlike the structure-conduct-performance or the production function approaches mentioned earlier, Ganapati is able to make statements about demand, marginal costs and fixed cost. While these statements depend on a significant number of maintained assumptions, they lead to a rich story about the underlying forces behind markup changes and they lead to both positive and normative implications associated with those changes. Ganapati's work on wholesaling reveals an evolving industry with endogenous tradeoffs in product quality, marginal cost and fixed cost.

The airline industry provides another example of increasing markups being associated with some degree of product improvement and marginal cost decline (Berry 1990), but it also illustrates that poorly policed mergers can increase prices. Debates over airline mergers often pivot on the negative effects of increased markups on some concentrated nonstop routes versus the potential for improved route structures leading to better choices and increased competition on other (often connecting) itineraries. ${ }^{3}$ Borenstein (1990) notes the strong evidence that prices rose after at least two Reagan-era mergers of airlines with largely

\footnotetext{
${ }^{3}$ These debates follow on the emphasis on improved airline product quality in Carlton, Landes, and Posner (1980) versus the emphasis on airline market power in Borenstein (1990).
} 
overlapping route networks. A more recent airline merger wave has consolidated the remaining legacy carriers into three large firms that face competition from Southwest Airlines and a group of new low-cost carriers. We still await a full academic evaluation of these mergers. The many years of near zero-profit operations of major airlines (Borenstein 2011), lasting up until the demand boom and merger wave of recent years, suggests that for a long time high markups over marginal cost in the industry were offset by the costs of running a large hub and spoke networks. These networks create large benefits by providing low-priced and convenient connections through hubs to many destinations. But they also have allowed airlines to charge high markups on many direct flights out of hub airports (Berry, Carnall. and Spiller, 2006).

Airlines, then, provide a rich but mixed example of the sources of markups. Running a hub and spoke network does involve endogenous fixed and sunk costs, but the possible effects of mergers on prices suggests a large role for antitrust policy in reducing harmful effects on consumers. The firms that provide local cable television and internet broadband may offer another example of monopoly rents (from deregulated physical connections at the household level) plus improved product quality (from new channels and increased speed), with markups protected in large part by the high fixed cost of adding new wired connections at the household level. It may well be that consumer surplus (and "output") is increasing in this industry, but not by as much as it would under alternative regulatory structures.

In other industry studies, higher concentration and markups do not seem to be accompanied by any improvement in quality. For example, many studies have shown that hospital consolidation between close competitors leads to substantial increases in price and markups without improving quality (for example, Town and Vistnes 2001; Capps, Dranove, and Satterthwaite 2003; Gowrisankaran, Nevo, and Town 2015; Ho and Lee 2017), or reductions in quality in price-regulated markets such as Medicare or the English National Health Service (Kessler and McClellan 2000; Cooper et al. 2011; Gaynor, Moreno-Serra, and Propper 2013; Gaynor, Propper, and Seiler 2016). For an overall review of this literature, see Gaynor, Ho, and Town (2015). With the exception of the associations identified by Cooper at al. (2019), research has not focused on identifying the major industry-wide factors driving higher hospital prices or markups. There has been little work examining entry or recovering fixed costs (for an exception see Abraham, Gaynor, and Vogt, 2007), or whether fixed costs are rising. Moreover, it should be noted that separately identifying costs and rents is a challenge in the hospital industry. Many hospitals (particularly the largest) are not-for-profit, thus rents tend to be spent and appear as expenses (as is true for not-for-profit firms in general). Identifying and understanding the major factors driving increased hospital markups is a key next step in understanding this market.

A final issue is that when markups are measured as a ratio of prices to marginal costs, the rise in markups may be driven by very low marginal costs, as in a number of media and internet markets. For example, Waldfogel (2015) documents that in the recorded music industry, digitization lowered marginal distribution costs and the fixed costs of production, although "quality" is still produced via endogenous fixed costs. These lower costs led to an explosion of product variety. In such media and internet information markets, the "macro-production markup," measured as the ratio of price to marginal cost, may go to near infinity as marginal 
cost of product the product declines to near zero, as long as price remains clearly positive. Similarly, monopsony power can in principle also be a driver of increased markups via reduced marginal costs.

We have provided examples of three kinds of results from detailed industry studies. In some cases like wholesaling), investments may be generating product quality improvement together with a shift from marginal to fixed costs, generating an improvement in consumer welfare. In other industries like airlines, markups may be associated with some quality improvement, but some mergers have also clearly resulted in price increases. In other markets like hospitals, there is no evidence that consolidation is resulting in systematic product quality improvements, or clear cost reductions, but there is strong evidence of price increases (or quality reductions). The diversity of results across these industries is evidence of the value and richness that can be obtained from careful industry studies. It also serves as a caution of the difficulties of drawing useful inferences from aggregate studies across industries.

Industrial organization industry studies, taken as a whole, do provide evidence against some particularly simple or stylized models. These studies clearly reject models that would closely approximate perfect competition. Similarly, these studies emphasize important game-theoretic oligopoly features of markets, rejecting simple interpretations associated with the "Chicago School" of antitrust (for example, Bork 1978).

Instead, these industrial organization studies also suggest a nuanced reality, in which large firms are in fact changing products and production methods, including the mix of marginal and fixed costs, over time. The industry studies seem to suggest is that "fixed costs" are often actually sunk costs that are built up through time via investments in networks, product quality, geographic location, and so forth. An interesting question is how this possible reallocation from marginal to fixed costs affects labor demand. Another important question is whether the share of labor in variable cost is higher or lower than the share of labor in fixed costs. ${ }^{4}$

Of course, the discussion here covers just a small collection of industry studies. In our view, industry-level studies are required to understand the forces shaping markets in the modern economy, and thereby to craft appropriate policies. These studies will have to take on broader segments of the overall economy if they are to fully respond to questions about aggregate

\footnotetext{
${ }^{4}$ As a contrast with this portrayal of evolving industries, a number of studies of mark-ups are based on stronger assumption. As one example, consider the (intentionally) highly stylized model of Autor et al. (2017). In that model, firms exogenously differ in their Hicks-neutral productivity shocks. There is a fixed labor requirement, common to all firms, which explains the negative correlation between firm size and the labor share. Motivated by the results from their firm-level production-side data, changes in industry average markups over time are then explained by a reallocation of market share (as through lower trade or search costs). As more consumers purchase from the largest firms, the fixed labor requirement is spread over yet more units, raising markups still further.
} 
markup trends. Also, while many existing industrial organization industry-level studies provide information on the level of markups, we would welcome a surge of industry-level research focused on trends in markups, to discover where they are rising and why. By their nature, detailed industry studies will tend to produce estimates and explanations for markups that are more complex than those advanced in studies making use of broad-based financial accounting data or Census data aggregated across large numbers of firms in very different industries. Focusing at the industry level allows researchers to study the ways in which firms seek to create competitive advantages with a mixture of strategies, including investment in fixed capital, changes in product quality, geographic advantage, and consolidation by merger.

\section{Factors Leading to Rising Markups}

It seems plausible that some of the primitives modern industrial organization-cost, conditions, demand conditions, and pricing environment-- have been changing over the last few decades. For example, the adoption of information technology is often a fixed cost involved hardware, such as servers, or software, such as enterprise resource planning software. Thus, firms and industries that have had information technology grow in importance have rising fixed costs, which leads to rising markups, and can lead to markets dominated by one or a small number of large firms. On the demand side, growing importance of network effects can lead to one or a small number of firms dominating a market and thus commanding higher markups. With regard to firm conduct, increased managerial exploitation of market power can lead to rising markups, as can the documented slow decline in US antitrust enforcement (for example, Baker 2019). In this section, we consider the available evidence on the factors that have been leading to rising markups.

\section{Rising Fixed and Sunk Costs}

We have already mentioned models of Shaked and Sutton (1982) and Sutton (1991), where fixed (and often sunk) costs at the firm level partly reflect endogenous choices of product quality, production techniques, and marketing. Under the assumptions of these models, industries do not deconcentrate even as market size grows, because there is always an incentive for some firm to become large, relative to the market, by making a sunk investment that drives up demand for its product.

Sutton (1991) gives examples where the better product does not involve much higher marginal cost (or can even involve reduced marginal cost) and therefore competition from lower quality competitors does not compete away the markup of the firm producing the high quality product. He argues that, during the period from the late nineteenth to mid twentieth century, decreasing transportation costs and national marketing strategies allowed many consumer goods products to trade higher fixed costs for national sales dominance. These firms maintained high markups and high national market shares in the absence of important scale economies of production. If Census data on production had existed during that period, it might 
have revealed a trend of increasing markups in consumer goods markets, with much of the markup attributable to a small number of "superstar" products.

What changes in the last few decades might allow firms to pursue a similar strategy of higher fixed costs and sustained market dominance? If a rise in the quality of services can be achieved with higher spending on information technology, and if a large component of information technology spending represents fixed costs, then the proportion of fixed to variable cost will be rising across the decades of increasing technological advancement. For example, Bessen (2017) provides evidence that customized software - used routinely by large corporations today requires large upfront fixed sunk costs. Calligaris, Criscuolo and Luca (2018) find higher markups in more digitally intensive industries, and in addition find that differences in markups between digitally intensive and non-intensive industries have grown.

These patterns are consistent with the hypothesis that rising fixed sunk costs and lower marginal cost due to increases in information technology investments could be a significant driver of increasing markups. In studying this hypothesis, how can researchers measure fixed and sunk costs? As noted, industrial organization economists have often been suspicious of attempts to directly measure fixed costs from accounting or Census data, because accounting rules do not follow economic principles for expensing, depreciation, rents on existing assets and so forth. ${ }^{5}$ Thus, industry-level studies typically estimate fixed (or sunk) costs as a kind of residual that explains the observed equilibrium market structure (or pattern of entry and exit) (Bresnahan and Reiss 1990; Berry 1992; Ciliberto and Tamer 2009; Berry, Eizenberg, and Waldfogel 2016). Fixed costs are bounded above by the level that would render existing firms unprofitable, and below by the level that would induce incremental entry.

However, this approach treats fixed costs as exogenous. In some instances, a firm can choose its fixed costs, like how its level of advertising and promotion, or of research and development. Treating fixed costs as endogenous is also consistent with evidence for the increased importance of intangible assets, which include management effectiveness, business processes, intellectual property, branding, and the effective use of information technology, as documented by Corrado, Hulton and Sichel (2009), Haskel and Westlake (2017), and Bhandari and McGrattan (2018). Firms' market shares are positively correlated with their intangible assets, as Crouzet and Eberly (2018) demonstrate. Moreover, they show that in some sectors like consumer goods, higher intangible assets are positively correlated with higher productivity, while in other sectors like health care, intangible assets are correlated with higher measured markups. A rising role of intangible assets will further complicate the use of accounting data to discuss markups, since these assets may be treated in an inconsistent fashion in accounting data (Yurokoglu 2018).

The welfare consequences of increasing sunk and fixed costs in an industry are complex, probably industry-specific, and may vary across antitrust and regulatory regimes. On the

\footnotetext{
${ }^{5}$ This point is related to arguments in Fisher and McGowan (1985) and Schmalensee (1989) about general problems with depreciation, accounting data, and measured components of profit and cost.
} 
consumer side, higher fixed costs may enable a rise in product quality, which is generally good. However, fixed costs may be duplicated by competitors, such that oligopoly generates excessive entry from the social welfare perspective (Mankiw and Whinston 1986; Berry and Waldfogel 1999). Moreover, better products may contribute to higher markups, especially if the high fixed (and/or sunk) costs limit the number of competing firms and drive up prices. Alternatively, higher markups can reflect falling marginal costs, rather than higher prices.

On the firm side, fixed costs must be offset by positive markups in order for the firm to survive. Therefore, industries with high markups may or may not be profitable. Profits in excess of those necessary to cover current fixed costs might reflect a return on past investments; indeed, the expectation of a current stream of profits may have been necessary to bring forth a socially valuable innovation. In other cases, current profits may reflect a rent on past luck or may result from a past sunk investment is that preventing socially desirable entry (for the modern game theory of sunk costs and entry barriers, see Tirole 1988). It is difficult to see how cross-industry studies can capture the industry-level complexity that results from high fixed and sunk costs.

The distributional consequences of higher fixed costs, perhaps combined with lower marginal costs, can be equally complex. For example, it is easy to imagine cases where labor is particularly associated with variable product costs, while (for example) fixed costs are associated with the employment of software engineers and with returns to various forms of intellectual property. In some cases, imputed fixed costs may reflect rents that do not serve an efficiency-enhancing purpose. For example, one possible rent involves a return to a (possibly lucky) first-mover advantage in a network industry, as we discuss in the next subsection.

In our opinion, both industry studies and accounting data studies point to the broad category of endogenously increasing fixed and sunk costs as an important, perhaps the most important, source of the apparent pattern of rising global markups. In the next section, we focus on the specific case of network effects, which create particular complexities.

\section{Network Effects}

Network effects have become important in many sectors of the economy. In particular, they are often strongly present in digital platforms (US Bureau of Economic Analysis 2018), where many consumers rely on platforms with user-provided content regarding restaurants, hotels, traffic, and news. Network effects lead to markets dominated by one or a small number of firms, as in social media.

A rising importance of network effects can lead to weaker competition and thus higher markups in various ways. First, network effects tend to lead to consumer lock-in, enhancing firms' short-run market power while making new entry difficult. Second, network effects can make fixed costs more important, including expansions of information technology, distribution, delivery and promotion in order to reach a larger number of customers. Third, the aggregation of eyeballs and consumer information by platforms may give an advantage to the dominant 
business in selling advertising, and thus perpetuate a concentrated market structure (Bergemann and Bonatti 2018). For these reasons, the locus of competition in network markets often turns out to be for the market, not in the market. Once a firm has come to dominate a network market. its market position is not easily eroded.

The lucky first-mover in a market with network effects will benefit from these effects. Thus, markups in this instance include a rent on that luck, and there is no reason to believe that the (expected) market rent was required to generate the initial investment effort. Of course, the network can also create substantial consumer surplus. The policy question is whether some alternative antitrust or regulatory structure could improve the market outcome, while retaining the consumer benefits.

\section{Growing Monopsony Power}

Claims have been made that the concentration of employers is growing in labor markets, and that more concentrated employer markets are associated with lower wages (Azar, Marinescu, and Steinbaum 2019; Azar, Marinescu, Steinbaum, and Taska 2018; Naidu, Posner, and Weyl 2018). ${ }^{6}$ To the extent that these forces trended toward more monopsony power or more exercise of monopsony power over the last decades, the declining cost of labor, typically a variable cost, may have contributed to the trend in markups.

There is long-standing evidence of monopsony power in some labor markets, notably the markets for nurses (Sullivan 1989; Currie, Farsi, and MacLeod 2005; Staiger, Spetz, and Phibbs 2010) teachers (Ransom and Sims 2010), and fast food workers (Card and Krueger 1994). However, there is evidence that the extent of monopsony power in the labor market, has grown over the years (Manning 2003). Some possible reasons include the decline in union membership, in the powers available to unions, and in legal remedies available to individual workers, all of which have weakened worker bargaining power (Farber et al 2018). There is also some evidence of the use of outsourcing by firms ("fissuring") to facilitate wage discrimination in a way that leads to lower average wages and higher markups (Weil 2011). There is speculation that the rise of the "gig" economy may be holding down worker wages as well (Dube 2010, Chen et al 2017). Another feature of labor markets that likely grew over the last decades but has only been uncovered recently is the use of non-compete clauses by employers in some industries (Starr, Prescott, and Bishara 2018), particularly for low wage workers in fast food and other franchises (Krueger and Ashenfelter 2018). ${ }^{7}$

\footnotetext{
${ }^{6}$ The finding is not universal. Lipsius (2018) and Rinz (2018) find that employer concentration has fallen, implying that monopsony power has fallen, not risen.

7 The Washington State Attorney General has challenged these noncompete agreements and by 2019 had achieved many dozens of settlements to not enforce and remove the provisions. Also, the Department of Justice has recently prosecuted multiple cases of firms explicitly agreeing not to hire away each other's workers (the "no poach" agreements), as well as naked collusion to fix wages that occurred over many years. One of the first of this recent group of cases involved many of the top employers among the Silicon Valley tech firms such as Apple,
} 
A main difficulty in this area is that most of the existing studies of monopsony and wages follow the structure-conduct-performance: that is, they argue that greater concentration of employers can be applied to labor markets, and then proceed to estimate regressions of wages on measures of concentration. For the same reasons we discussed previously, studies like this may provide some interesting descriptions of concentration and wages, but are not ultimately informative about whether monopsony power has grown and is depressing wages.

Recent efforts are being made to take a more sound empirical approach. Card et al. (2018) reviews the evidence on labor markets and reconciles a variety of empirical results via a model of "differentiated jobs" that recalls industrial organization models of differentiated products. Azar, Berry, and Marinescu (2019) estimate an industrial organization style model of differentiated job vacancy demand at the level of the job applicant applying for a specific job title within a commuting zone. They find moderately positive levels of firm market power even in labor markets that are not highly concentrated. However, this work estimates levels of labor market power, not trends over time.

Linkages can also arise between mergers and increased monopsony power. Prager and Schmitt (2019) examine the effect of mergers in the hospital industry, and find evidence that mergers between nearby hospitals depress wage growth for workers with hospital job-specific skills (but not for workers with general job market skills).

At present, the extent to which any decreased competition in the labor market is a major driver of increased markups is not clear, and research which sheds light on this question would be most welcome.

\section{Increased Rent Seeking}

Yet another potential explanation for higher markups that is that managers are increasingly better trained (perhaps in economics or MBA programs) to find and exploit situations where their firms face inelastic demand. Firms in many industries including airlines, entertainment, and retail have improved over time in their ability to price discriminate, presumably raising some markups while lowering others, with an uncertain implication for the distribution of markups. Traditionally, the economics profession has treated these situations as arbitrage of informational rents that guide economic activity and lead to an increase in efficiency (an idea attributed to Friedrich von Hayek). But once exposed to public scrutiny, these instances are often portrayed and perceived as exploitation of consumers.

Some firms have gone beyond more aggressive price discrimination, and have raised prices by engaging in holdup of a relationship-specific investment or by reneging on agreements that are not sufficiently protected by contract. As one example, pharmaceutical industry CEO Martin

Google, Adobe, Intel, Intuit, and Pixar (In re: High-Tech Employee Antitrust Litigation, N.D. Cal. Case 11-CV-02509LHK [2015]). 
Shkreli sharply increased the price of a generic drug in a marketplace where it takes several years for a competitor to be approved by the Food and Drug Administration (Pollack 2015). In another, holders of standard essential patents demanded high royalties from handset makers after networks implementing the standard were fully built out and could not be changed (Scott Morton and Shapiro 2016). In yet another example, hedge funds bought up the television stations that were needed to re-pack spectrum, so it could be used by wireless carriers, and strategically withheld those stations to raise the price of their assets (Doraszelski et al 2017). Physicians who are out-of-network with a certain insurer charge patients in the in-network hospital where they work three times as much as in-network physicians would charge (for an example of out-of-network billing for emergency care, see Cooper, Scott Morton, and Shekita 2018). When one of the outsourcing companies that perfected this strategy was written up in the New York Times and the strategy became public (Creswell, Abelson, and Sanger-Katz. 2017), insurers used the subsequent call for regulation to improve their bargaining positions in new contracts and the outsourcing company's profits fell.

To the extent that firms and their managers are becoming more sophisticated in their pursuit of inelastic niches where they can create and exploit market power, the relevant markups will rise. Research that sheds some light on the extent of this phenomenon, whether it has grown, and whether and to what extent it has contributed to increased markups would be beneficial.

\section{Globalization}

Although globalization is not our focus here, it may also be part of the explanation of rising markups for the highest markup firms. A market that contains some firms that globalize and others that do not could generate this pattern. Firms with a global supply chain will have access to lower cost inputs and may then achieve economies of scale, leading to a higher markup. If that globalized firm gains share at the expense of domestic rivals, industry markups will rise. Thus, increased globalization may play a role in both increasing markups and the unequal distribution of the increase. Uncovering what effects globalization may have had on markets and markups seems a potentially fruitful area for future research.

\section{Antitrust Enforcement}

There were undoubtedly some cases of overly aggressive enforcement of antitrust laws in the 1960s and '70s: in one much-discussed case, courts upheld blocking a merger that would have resulted in a combined market share of 7.5 percent (United States v. Von's Grocery Co., 384 U.S. 270 [1966]). However, courts in recent decades have been steadily dialing back antitrust enforcement, both through economic assumptions built in to jurisprudence as well as practical changes such as raising the pleading standards for plaintiffs (Baker 2019; Gavil 2019). Mergers in markets with more than two firms are much less likely to be challenged now than in past decades (Kwoka 2016)). The recent Ohio v. American Express Co. (138 S. Ct. 2274 (2018)) 
Supreme Court ruling has been interpreted by some as possibly ending the government's ability to bring an antitrust case against a platform that operates in a two-sided market (Khan 2019).

The decline of antitrust enforcement in recent decades may be a contributor to rising markups, although more research is needed to substantiate this conclusion firmly (Kulick 2017; Baker 2019; Wollmann 2019). However, antitrust enforcement and competition policy is important in this context, because unlike shifts in fixed costs and technology, it can be directly addressed via policy. Moreover, regardless of the role of changing antitrust enforcement in explaining a rise in markups, higher markups imply a world that may require increased antitrust vigilance.

Here, we provide an overview of some commonly-mentioned concerns about underenforcement of antitrust that are especially applicable to the large, high-markup firms most at issue: vertical restraints, coordinated effects, digital platforms, exploitation of intellectual property, acquisitions of potential competitors, and exclusionary conduct. These issues have been discussed in more detail in a number of other policy venues, including this issue (Shapiro 2019, Scott Morton et al 2019, Federico et al 2019, Baker 2019). We then offer some concluding thoughts on the appropriate perspective of antitrust enforcement given the current state of knowledge in these areas.

\section{Some Specific Concerns about Underenforcement of Antitrust}

Vertical restraints describes contracts between firms with a vertical relationship that may have anticompetitive effects depending on the type of restraint, the party using it, market structure, and so forth (Segal and Whinston 2000; Crawford et al. 2017; Conlon and Mortimer 2013; Asker 2016). These issues seem potentially important in the current situation where certain markets have come to be dominated by one or a small number of large firms. A common situation is that high-markup platform firms succeed by offering valuable (often digital) goods and services to consumers, but then competition issues arise when the platform either begins to supply the complementary products itself, or contracts over price, quality, or technology in a way that limits the independent complements on the platform. Raising rivals' costs, foreclosure, and exclusion are among the possible theories of harm that can be raised in this setting. The Vertical Merger Guidelines of the US Department of Justice were last updated in 1984, and the federal agencies rarely bring such cases. The government litigated its first vertical merger case in 40 years in 2018, arguing that proposed vertical merger between AT\&T and Time Warner was anticompetitive, but lost convincingly at the federal appeals court level (US V. AT\&T INC., DirecTV Group Holdings, LLC, and Time Warner Inc. 310 F.Supp.3d 161 [2018]).

Coordinated effects refers to a situation in which concentrated industries or sectors may be more susceptible to tacit collusion (Tirole 1988). Recent empirical work has found tacit collusion to be unexpectedly prevalent (Miller and Weinberg 2017; Ciliberto and Williams 2015; Schmitt 2018), but in general the economics profession has contributed little to this policy area. In a world with trends towards concentration, more understanding and measurement of tacit collusion would be valuable. 
The rise of digital platforms has been an important change in the economy, sparking rising calls from some quarters for antitrust action against firms like Amazon, Facebook, and Google (Khan 2016, Wu 2018, Hughes 2019 ). The European Commission has been active in this area, raising issues that include allegations of exclusionary bundling, anticompetitive exclusive contracts, vertical foreclosure, and anticompetitive mergers. In our view, establishing robust theories of harm and tools to evaluate the evidence for or against digital platforms are valuable activities for the antitrust agencies as well as academic economists. However, US antitrust agencies have not been active in this area with the exception of the investigation by the Federal Trade Commission (US Federal Trade Commission 2013) that led to a settlement but no case.

Firms may use patents or other intellectual property to engage in exclusionary conduct in related markets. For example, branded drugs have long used patent litigation settlements as a way to pay generic rivals to stay out of the market (called "reverse payments" or "pay for delay"). It took 18 years from the time the Federal Trade Commission first identified this strategy to the time when the US Supreme Court ruled that it can, under certain conditions, be illegal (FTC v. Actavis, Inc., 570 U. S. 136 [2013]). Pharmaceutical firms have also used "patent thickets" and "product hopping" (for example, changing dosages or packaging) to prevent competitive entry or substitution. Patent litigation can be used as a strategy by firms with large portfolios to discourage investment and innovation or to partner with an incumbent firm to disadvantage rivals: as one example, the Federal Trade Commission successfully sued Qualcomm for such tactics involving the use of a key semiconductor device used in smartphones (for background, see https://www.ftc.gov/enforcement/cases-proceedings/1410199/qualcomm-inc ). A similar result occurs when a standard-setting organization for an industry sets a standard that requires the use of an essential patent-and then the firm holding that patent denies rivals access to patent on fair, reasonable, and nondiscriminatory terms. In work on causes behind a rise in dominant firms and a fall in US business dynamism, Akcigit and Ates (2019) suggest that one cause is "a heavy use of intellectual property protection by market leaders to limit the dissemination of knowledge."

Acquiring potential entrants when they are still small can be a way for a dominant firm to improve quality, or to fold a complement into its core product-or just to block a future potential entrant. Traditional antitrust enforcement has often focused more on whether a merger led to an immediate significant increase in market share, not on how it affected potential or nascent competition. But when a market is subject to strong network effects, competition is for the market, and the possibility that the nascent entrant could contest the incumbent is an important source of competition. Frequently mentioned anecdotes include big tech companies' acquisitions of small firms in adjacent product markets, such as Facebook's acquisitions of Instagram and WhatsApp. In a study of the pharmaceutical industry, Cunningham, Ederer and $\mathrm{Ma}$ (2018) conclude that about 6.4 percent of pharma acquisitions are "killer acquisitions," where the acquisition eliminates entry by a potential competitor. However, both the probability and the value of potential entry are uncertain, and research on identifying or measuring these effects in different settings would be extremely useful. 
"Exclusionary conduct" arises when large incumbent firms with low marginal costs undertake activities that deter entry or disadvantage existing rivals. Two of the many possible examples of exclusionary conduct especially relevant in the current context include most-favored-nation contracts and refusals to deal.

"Most-favored-nation" (MFN) contracts (a term lifted from international trade treaties) specify that a seller must give the buyer who has such a contract as good a price as that seller gives to any other buyer. This may appear pro-competitive. But notice that MFN makes price discounts more costly for the seller - any discount to any other buyer must also be provided to the buyer with the MFN contract. For example, imagine the firms interacting on a large digital platform, like hotels, agree to sign an MFN contract with the platform (Boik and Corts 2016; Baker and Scott Morton 2018). If a rival digital platform with a lower commission (say, 10 percent instead of 25 percent) enters and contracts with the same hotels, the hotel room must be priced as high on the low-margin platform as it is on the high-margin platform, and the lower-cost distribution channel may fail to gain traction. These practices have been challenged in Europe, but not in the United States (Mantovani, Piga, and Reggiani 2019).

Refusals to deal and foreclosure can be an attempt to weaken competition. The EC's case against Google's search engine illustrates this issue (European Commission 2017). Suppose a provider of local service listings is a complement to general search; namely, a consumer can search on Google and find a Yelp page that holds the desired information. Displaying the Yelp page and letting consumers learn about it may allow Yelp to establish an independent relationship with consumers. The platform can use its rules to determine the display of organic results and the selection of ads shown, and in this way may be able to steer consumers away from such a complement. The platform could have a financial interest in doing so because of the risk that consumers learn to go straight to Yelp, reducing single-homing and the market power of the platform. This strategy might be even more attractive if the platform sells its own (vertically integrated) similar local search product, and can divert revenues from local search advertising to itself by steering customers to its own product. (Or perhaps it could raise its rival's costs by requiring it to purchase an ad in order to obtain consumers.) Foreclosure strategies of this type can reduce competition in either the underlying platform market, or possibly in competition among services provided on the platform.

As the economy becomes increasingly digital, possessing data can be another way to limit competition. For example, health care systems often refuse or make it difficult to transmit patients' data to alternative health care providers, with the explicit goal of retaining patients (Savage, Gaynor, and Adler-Milstein 2019). Anticompetitive use of data is another method of exclusion. The US Department of Justice recently settled a case against a large hospital system for employing clauses in their contracts with insurers that prevented insurers from providing patients information or incentives that would direct them to lower cost or higher value hospitals (United States and the State of North Carolina v. Carolinas Healthcare System, https://www.justice.gov/atr/case/us-and-state-north-carolina-v-charlotte-mecklenburghosptial-authority-dba-carolinas). Another such case is being pursued by the Attorney General 
in California (People of the State of California Ex. Rel. Xavier Becerra v. Sutter Health, https://oag.ca.gov/system/files/attachments/press releases/Sutter\%20Complaint.pdf).

\section{Moving Forward with Antitrust in a Situation of Uncertainty}

Much of the evidence regarding rising markups seems to us plausible and worthy of further investigation, although uncertainty remains as to the most important causes of rising markups. Despite these uncertainties, the research base does provide some guidance for policy (for a decision theoretic approach to antitrust enforcement, see Baker 2015). We do know that competitive markets are generally beneficial for consumers. We also know that market power, once acquired, can be durable due to many of the economic and strategic issues discussed above. In particular, a substantial game-theoretic literature emphasizes the role of sunk costs in maintaining high markups (Tirole 1986). There are many examples in US economic history, including IBM and Microsoft, in which substantial market power persisted over decades.

The potential benefits of a number of forms of antitrust enforcement are robust to the magnitudes that future research on these issues may uncover. If the goal is to reduce market power, the most useful focus for antitrust enforcers is likely to be on conditions of entry, including acquisitions by existing of recent or potential entrants, along with exclusionary conduct. Without rules to ensure there is competition on the merits, existing market power can be leveraged to create future market power and generate the durability that appears in the data. Consistent vigorous antitrust enforcement can ensure that concentration does not perpetuate itself because entry is not protected.

It's worth remembering that government agencies besides the antitrust authorities at the Federal Trade Commission and the US Department of Justice can have significant impacts on entry, market structure, and competition. For example, rules from the Food and Drug Administration hinder entry of biosimilar drugs. The Department of Health and Human Services permits higher fees to be charged for the same physician service if the service is provided in a doctor's office owned by a hospital, and permits hospitals (but not doctors) to obtain substantial discounts on expensive drugs (like those for treating cancer) that are administered by physicians (the "Section 340B" program). These policies unintentionally encourage consolidation, since hospitals and physician practices can share the rents from these regulatory loopholes if the practices are owned by hospitals. Rules from the US Department of Transportation (2017) affect the transparency of airline fees. The US Patent and Trademark Office's (PTO) decisions to issue low quality patents enables the activities of patent trolls. The Federal Communications Commission sets rules that give multichannel video programming distributors greater or lesser power to limit content provision by online video providers. At the state level, legislatures respond to the desires of incumbent car dealers by passing laws preventing the entry of new car brands into the state (Tesla Motors, Inc. $v$. Johnson et al., W.D. Mich. Civil Action 16-cv-1158 [2017]; Gavil, Feinstein, and Gaynor 2014). 
In summary, a wave of industry-level econometric studies are needed to help us understand shifts in mark-ups, the underlying causes, and more broadly how markets in our modern economy are functioning and evolving. Many of the likely causes of rising markups in this paper involve economic shifts that do not have any direct policy response. But whatever the underlying cause and size of rising markups, there are several policy levers along the lines mentioned here that could be used to promote competition. 


\section{References}

Abraham, Jean M., Gaynor, Martin, and William B. Vogt. 2007. "Entry And Competition In Local Hospital Markets." Journal of Industrial Economics, 55(2): 265-288.

Akcigit, Ufuk, and Sina T. Ates. 2019. "What Happened to U.S. Business Dynamism?" Becker

Friedman Institute Working Paper. April 15. https://bfi.uchicago.edu/workingpaper/what-happened-to-u-s-business-dynamism/./

Asker, John. 2016."Diagnosing Foreclosure Due to Exclusive Dealing." Journal of Industrial Economics. 64(3): 375-410.

Autor, David, David Dorn, Lawrence F Katz, Christina Patterson, and John Van Reenen. 2017. "The Fall of the Labor Share and the Rise of Superstar Firms." NBER Working Paper No. 23396.

Azar, José , Steven Berry, and Ioana Marinescu. 2019. "Estimating Labor Market power." Unpublished.

Azar, José , Ioana Marinescu, and Marshall Steinbaum. 2017. "Labor Market Concentration."NBER Working paper No. 24147.

Azar, José , loana Marinescu, Marshall Steinbaum, and Bledi Taska. 2018. "Concentration in US Labor Markets: Evidence from Online Vacancy Data." NBER Working Paper No. 24395.

Baker, Jonathan B. 2015. "Taking the Error Out of 'Error Cost' Analysis: What's Wrong with Antitrust's Right." Antitrust Law Journal.

Baker, Jonathan B. 2019. The Antitrust Paradigm. Harvard University Press.

Baker, Jonathan B., and Fiona Scott Morton. 2018. "Antitrust Enforcement Against Platform MFNs." The Yale Law Journal 127 (7): 1742-2203.

Barkai, Simcha. 2017. "Declining Labor and Capital Shares." Working Paper, London Business School.

Benmelech, Efraim, Nittai Bergman, and Hyunseob Kim. 2019. Strong Employers and Weak Employees: How Does Employer Concentration Affect Wages? Working Paper, Northwestern University.

Bergemann, Dirk, and Alessandro Bonatti. 2018. "Markets for Information: An Introduction." Cowles Foundation Discussion Paper No. 2142.

Berry, Steven T. 1990. "Airport Presence as Product Differentiation." The American Economic Review 80 (2): 394-399.

Berry, Steven. 1992. "Estimation of a Model of Entry in the Airline Industry." Econometrica 60(4): 889-917.

Berry, Steven, Mike Carnall and Pablo Spiller (2006), "Airline Hubbing, Costs and Demand," in Advances in Airline Economics, Vol. 1: Competition Policy and Anti-Trust, D. Lee, ed. Elsevier Press 183-214.

Berry, Steven, Alon Eizenberg, and Joel Waldfogel. 2016. "Optimal product variety in radio markets." RAND Journal of Economics ( RAND Corporation) 47 (3): 463-497.

Berry, Steven, and Philip Haile. 2014. "Identification in Differentiated Products Markets Using Market Level Data." Econometrica vol. 82(5): 1749-1797. 
Berry, Steven, and Joel Waldfogel. 1999. "Free Entry and Social Inefficiency in Radio Broadcasting." The RAND Journal of Economics 30(3): 397-420.

Bessen, James E. 2017. "Information Technology and Industry Concentration." Boston University School of Law, Law and Economics Research Paper No. 17-41.

Bhandari, A, and E R McGrattan. 2018. "Sweat Equity in U.S. Private Business." NBER Working Paper No. 24520. Federal Reserve Bank of Minneapolis Staff Report 560.

Boik, Andre, and Kenneth S. Corts. 2016. "The Effects of Platform MFNs on Competition and Entry." The Journal of Law and Economics 59 (1): 105-134.

Borenstein, Severin. 1990. "Airline Mergers, Airport Dominance, and Market Power." American Economic Review 80(2): 400-404.

Borenstein, Severin. 2011. "Why Can't US Airlines Make Money?" American Economic Review 101(3): 233-237.

Bork, Robert H. 1978. The Antitrust Paradox. New York: Free Press.

Bresnahan, Timothy f. 1989. "Empirical studies of industries with market power." In Handbook of Industrial Organization, edition 1, volume 2, , edited by Richard Schmalensee \& Robert Willig, 1011-1057. Amsterdam: Elsevier.

Bresnahan, Timothy F., and Peter C. Reiss. 1990. "Entry in Monopoly Markets." The Review of Economic Studies 57(4): 531-553.

California Attorney General Press Release. 2018. "Attorney General Becerra Sues Sutter Health for Anti-competitive Practices that Increase Prices for California Families." State of California Department of Justice - Office of the Attorney General. March 30. https://oag.ca.gov/news/press-releases/attorney-general-becerra-sues-sutter-healthanti-competitive-practices-increase.

Calligaris, Sara, Chiara Criscuolo, and Marcolin Luca . 2018. "Mark-Ups in the Digital Era." OECD Science, Technology and Industry Working Papers, No. 2018/10.

Capps, Cory, David Dranove, and Mark Satterthwaite. 2003. "Competitition and Market Power in Option Demand Markets." RAND Journal of Economics 34(4): 737-63.

Card, David, Ana Rute Cardoso, Joerg Heining, and Patrick Kline. 2018. "Firms and Labor Market Inequality: Evidence and Some Theory." Journal of Labor Economics 36 (S1): S13-S70.

Card, David, and Alan B. Krueger. 1994. "Minimum Wages and Employment: A Case Study of the Fast-Food Industry in New Jersey and Pennsylvania." American Economic Review 84 (4): 772-793.

Carlton, Dennis W., William M. Landes, and Richard A. Posner. 1980. "Benefits and Costs of Airline Mergers: A Case Study." Bell Journal of Economics 11(1): 65-83.

Chen, M. Keith, Judith Chevalier, Peter Rossi, and Emily Oehlsen. 2017. "The Value of Flexible Work: Evidence from Uber Drivers," NBER working paper 23296.

Ciliberto, Federico, and Tamer Elie. 2009. "Market Structure and Multiple Equilibria in Airline Markets." Econometrica 77 (6): 1791-1828.

Ciliberto, Federico, and Jonathan W. Williams. 2015. "Does Multimarket Contact Facilitate Tacit Collusion? Inference on Conduct Parameters in the Airline Industry." 45 RAND Journal of Economics 45(4):764-91.

Conlon, Christopher T., and Julie Holland Mortimer. 2013. "Efficiency and Foreclosure Effects of Vertical Rebates: Empirical Evidence." NBER Working Paper 19709. 
Cooper, Zack, Craig, Stuart V., Gaynor, Martin, and John Van Reenen. 2019. "The Price Ain't Right? Hospital Prices and Health Spending on the Privately Insured." The Quarterly Journal of Economics, 134(1): 51-107.

Cooper, Zack, Stephen Gibbons, Simon Jones, and Alistair McGuire. 2011. "Does Hospital Competition Save Lives? Evidence from the English NHS Patient Choice Reforms." Economic Journal 121 (554): F228-60.

Cooper, Zack , Fiona Scott Morton, and Nathan Shekita. 2018. "Surprise! Out-of-Network Billing for Emergency Care in the United States." NBER Working Paper No. 23623.

Corrado, Carol, Charles Hulten, and Daniel Sichel. 2009. "Intangible Capital and Economic Growth." Review of Income and Wealth.

Cowling, Keith, and Michael Waterson. 1976. "Price-Cost Margins and Market Structure." Economica, vol. 43, issue 171 267-274.

Crawford, Gregory S. , Robin S. Lee, Michael D. Whinston, and Ali Yurukoglu. 2017. "The Welfare Effects of Vertical Integration in Multichannel Television Markets." Econometrica 43(171):267-74.

Creswell, Julie, Reed Abelson, and Margot Sanger-Katz. 2017. "The Company Behind Many Surprise Emergency Room Bills." The New York Times, July 242017.

Crouzet, Nicolas, and Janice Eberly. 2018. "Intangibles, Investment, and Efficiency." AEA Papers and Proceedings 108(1): 426-31.

Cunningham, Colleen, Florian Ederer, and Song Ma. 2018. "Killer Acquisitions." https://ssrn.com/abstract=3241707.

Currie, Janet, Mehdi Farsi, and W. Bentley MacLeod. 2005. "Cut to the Bone? Hospital Takeovers and Nurse Employment Contracts." Industrial and Labor Relations Review 58 (3): 471-93.

De Loecker, Jan , and Jan Eeckhout. 2017. "The Rise of Market Power and the Macroeconomic Implications." NBER Working Paper No. 23687.

De Loecker, Jan, and Jan Eeckhout. 2018a. "Global Market Power." NBER Working Paper No. 24768.

De Loecker, Jan, and Jan Eeckhout. 2018b. "Some Thoughts on the Debate about (Aggregate) Markup Measurement." http://www.janeeckhout.com/wpcontent/uploads/Thoughts.pdf.

Demsetz, Harold. 1973. "Industry Structure, Market Rivalry, and Public Policy." Journal of Law and Economics 16(1): 1-9.

Doraszelski, Ulrich, Katja Seim, Michael Sinkinson, and Peichun Wang. 2017. "Ownership Concentration and Strategic Supply Reduction." NBER Working Paper No. 23034.

Dube, Arindrajit and Ethan Kaplan. 2010. "Does Outsourcing Reduce Wages in the Low-Wage Service Occupations? Evidence from Janitors and Guards" Industrial and Labor Relations Review. 63(2): 287-306.

Eggertsson, Gauti B. , Jacob A. Robbins, and Ella Getz Wold. 2018. "Kaldor and Piketty's Facts: The Rise of Monopoly Power in the United States." NBER Working Paper No. 24287.

European Commission. 2017. Google Search (Shopping), CASE AT.39740

Farber, Henry S., Daniel Herbst, Ilyana Kuziemko, and Suresh Naidu. 2018. "Unions and Inequality Over the Twentieth Century: New Evidence from Survey Data." NBER Working Paper No. 24587. 
Farrell, Joseph , and Carl Shapiro. 1990. "Horizontal Mergers: An Equilibrium Analysis." The American Economic Review, Vol. 80, No. 1 107-126.

Federico, Giulio, Fiona Scott Morton and Carl Shapiro. Forthcoming. "Antitrust and Innovation: Welcoming and Protecting Disruption." Chap. 4 in Innovation Policy and the Economy, vol. 20, edited by Josh Lerner and Scott Stern. Chicago: University of Chicago Press.

Fisher, Franklin , and John McGowan. 1983. "On the Misuse of Accounting Rates of Return to Infer Monopoly Profits." American Economic Review, vol. 73(1): 82-97.

Furman, Jason. 2015. "Business investment in the United States: Facts, explanations, puzzles, and." Technical report, Council of Economic Advisers, Executive Office of the President of the United States.

Furman, Jason, and Peter Orszag. 2018. "A Firm-Level Perspective on the Role of Rents in the Rise in Inequality." Chap. 1 in Toward a Just Society: Joseph Stiglitz and Twenty-First Century Economics, edited by Martin Guzman, 19-47. New York: Columbia University Press.

Ganapati, Sharat. 2018a. "Oligopolies, Prices, Output, and Productivity." https://ssrn.com/abstract=3030966.

Ganapati, Sharat. 2018b. "The Modern Wholesaler: Global Sourcing, Domestic Distribution, and Scale Economies."

https://www.tuck.dartmouth.edu/uploads/content/Ganapati_Wholesalers_2016_copy. pdf.

Gavil, Andy, Debbie Feinstein, and Marty Gaynor. 2014. "Who Decides How Consumers Should Shop?" Competition Matters (blog), US Federal Trade Commission, April 24, 2014. https://www.ftc.gov/news-events/blogs/competition-matters/2014/04/who-decideshowconsumers-should-shop.

Gaynor, Martin , Kate Ho, and Robert J. Town. 2015. "The Industrial Organization of Health-Care Markets." Journal of Economic Literature 53(2): 235-284.

Gaynor, Martin, Rodrigo Moreno-Serra, and Carol Propper. 2013. "Death By Market Power: Reform, Competition, and Patient Outcomes in the National Health Service." American Economic Journal: Economic Policy 5(4): 134-66.

Gaynor, Martin, Carol Propper, and Stephan Seiler. 2016. "Free to Choose? Reform, Choice, and Consideration Sets in the English National Health Service." American Economic Review 106(11): 3521-57.

Gowrisankaran, Gautam, Aviv Nevo, and Robert Town. 2015. "Mergers When Prices Are Negotiated: Evidence from the Hospital Industry." American Economic Review 105 (1): 172-203.

Grullon, Gustavo, Yelena Larkin, and Roni Michaely. Forthcoming. "Are U.S. Industries Becoming More Concentrated?" Review of Finance.

Gutiérrez, Germán , and Thomas Philippon. 2017a. "Declining Competition and Investment in the U.S." NBER Working Paper No. 23583.

Gutiérrez, Germán, and Thomas Philippon. 2017b. "Investment-less Growth: An Empirical Investigation." Brookings Papers on Economic Activity, 2017(Fall): 89-169.

Hall, Robert. 2018. "New Evidence on the Markup of Prices over Marginal Costs and the Role of Mega-Firms in the US Economy." NBER Working Paper No. 24574. 
Haskel, Jonathan, and Stian Westlake. 2017. Capitalism without Capital: the rise of the intangible economy. Princeton, NJ: Princeton University Press.

Ho, Kate, and Robin S. Lee. 2017. "Insurer Competition in Health Care Markets." Econometrica 85(2): 379-417.

Huges, Chris. 2019. "It's Time to Break up Facebook" The New York Times, 9 May 2019. https://www.nytimes.com/2019/05/09/opinion/sunday/chris-hughes-facebookzuckerberg.html

Kessler, Daniel P., and Mark B. McClellan. 2000. “Is Hospital Competition Socially Wasteful?” Quarterly Journal of Economics 115(2): 577-615.

Khan, Lina. 2016 "Amazon's Antitrust Paradox" Yale Law Journal 126(3):710-805.

Khan, Lina. 2019. Blog post at https://www.vox.com/the-bigidea/2018/7/3/17530320/antitrust-american-express-amazon-uber-tech-monopolymonopsony

Krueger, Alan, and Orley Ashenfelter. 2018. "Theory and Evidence on Employer Collusion in the Franchise Sector." NBER Working Paper No. 24831.

Kulick, Robert. 2017. "Ready-to-Mix: Horizontal Mergers, Prices, and Productivity." US Census Bureau Center for Economic Studies Working Paper CES-WP-17-38. https://ssrn.com/abstract=2637961.

Kwoka John E. Jr. 2016. "The Structural Presumption and the Safe Harbor in Merger Review: False Positives, or Unwarranted Concerns?" https://ssrn.com/abstract=2782152.

Lipsius, Ben. 2018. "Labor Market Concentration Does Not Explain the Falling Labor Share." https://ssrn.com/abstract=3279007.

Mankiw , N. Gregory, and Michael Whinston. 1986. "Free Entry and Social Inefficiency." Rand Journal of Economics 17(1): 48-58.

Manning, Alan. 2003. Monopsony in Motion: Imperfect Competition in Labor Markets. Princeton NJ: Princeton University Press.

Mantovani, Andrea, Claudio A. Piga, and Carlo Reggiani. 2017. "The Dynamics of Online Hotel Prices and the EU Booking.Com Case ." Networks, Electronic Commerce and Telecommunications (NET) Institute Working Paper 17-04. https://ssrn.com/abstract=3049339.

Miller, Nathan H., and Matthew C. Weinberg. 2017. "Understanding the Price Effects of the MillerCoors Joint Venture" Econometrica 85(6): 1763-91.

Pollack, Andrew. 2015. "Drug Goes From \$13.50 a Tablet to \$750, Overnight," New York Times, September 20, 2015. https://www.nytimes. com/2015/09/21/business/a-hugeovernightincrease-in-a-drs-price-raises-protests.html.

Posner, Eric A., Glen Weyl, and Suresh Naidu. 2018. "Antitrust Remedies for Labor Market Power." Harvard Law Review 132(2): 536-601.

Prager, Elena, and Matt Schmitt. 2018. "Employer Consolidation and Wages: Evidence from Hospitals." Washington Center for EquitableGrowth Working Paper Series. https://equitablegrowth.org/working-papers/employerconsolidation-and-wagesevidence-from-hospitals/.

Ransom, Michael, and David Sims. 2010. "Estimating the Firm's Labor Supply Curve in a "New Monopsony" Framework: School Teachers in Missouri." Journal of Labor Economics 28 (2): 331-355. 
Raval, Devesh. 2019. "Testing the Production Approach to Markup Estimation." https://ssrn.com/abstract=3324849.

Ravenscraft, David. 1983. "Structure-Profit Relationships at the Line of Business and Industry Level", Review of Economics and Statistics 65(1): 22-31.

Rinz, Kevin. 2018. "Labor Market Concentration, Earnings Inequality, and Earnings Mobility." US Census Bureau Center for Administrative Records Research and Applications Working Paper 2018-10. https://www.census.gov/library/workingpapers/2018/adrm/carra-wp2018-10.html.

Rossi-Hansberg, Esteban, Pierre-Daniel Sarte, and Nicholas Trachter. 2019. "Diverging Trends in National and Local Concentration." https://www.princeton.edu/ erossi/DTNLC.pdf.

Savage, Lucia, Martin Gaynor, and Julia Adler-Milstein. 2019. "Digital Health Data and Information Sharing: A New Frontier for Health Care Competition?" Antitrust Law Journal 82(2): 592-621.

Schmalensee, Richard. 1989. "Inter-industry studies of structure and performance." In Handbook of industrial organization, by Richard Schmalensee and Robert Willig, 9511009. Elsevier.

Schmitt, Matt. 2018. "Multimarket Contact in the Hospital Industry." American Economic Journal: Economic Policy 361-387.

Scott Morton, Fiona, Pascal Bouvier, Ariel Ezrachi, Bruno Jullien, Roberta Katz, Gene Kimmelman, A. Douglas Melamed, and Jamie Morgenstern. 2019. Committee for the Study of Digital Platforms: Market Structure and Antitrust Subcommittee Report. Draft. Chicago: Stigler Center for the Study of the Economy and the State, University of Chicago Booth School of Business. https://research.chicagobooth.edu/media/research/stigler/pdfs/market-structure---report-as-of-15-may-2019.pdf.

Scott Morton, Fiona, and Carl Shapiro. 2016. "Patent Assertions: Are We Any Closer to Aligning Reward to Contribution?" Chap. 4 in Innovation Policy and the Economy, vol. 16, edited by Josh Lerner and Scott Stern, 89-133. Chicago: University of Chicago Press.

Segal, Ilya R., and Michael D. Whinston. 2000. "Naked Exclusion: Comment." American Economic Review 90 (1): 296-309.

Shaked, Avner, and John Sutton. 1982. "Relaxing Price Competition Through Product Differentiation,." The Review of Economic Studies Vol. 49, No. 1, 3-13.

Shapiro, Carl. 2019. "Protecting Competition in the American Economy: Merger Control, Tech Titans, Labor Markets" Journal of Economic Perspectives, forthcoming.

Smith, Noah. 2017. "America's Superstar Companies Are a Drag on Growth." Bloomberg, September 1, 2017. https://www.bloomberg.com/opinion/articles/2017-09-01/americas-superstar-companies-are-a-drag-on-growth.

Staiger, Douglas, Joanne Spetz, and Ciaran Phibbs. 2010. "Is There Monopsony in the Labor Market? Evidence from a Natural Experiment." Journal of Labor Economics 28 (2): 211236.

Starr, Evan, J.J. Prescott, and Norman Bishara. 2018. "Noncompetes in the U.S. Labor Force." $U$ of Michigan Law \& Econ Research Paper No. 18-013. https://ssrn.com/abstract=2625714.

Sullivan, Daniel. 1989. "Monopsony Power in the Market for Nurses." Journal of Law and Economics 32(2): S135-78. 
Sutton, John. 1991. Sunk costs and market structure, price competition, advertising, and the evolution of concentration. Cambridge MA: MIT Press.

Tirole, Jean. 1988. The Theory of Industrial Organization, Cambridge, MA: MIT Press.

Town, Robert, and Gregory Vistnes. 2001. "Hospital Competition in HMO Networks." Journal of Health Economics 20(5): 733-53.

US Bureau of Economic Analysis. 2018. "Initial estimates Show Digital Economy Accounted for 6.5 Percent of GDP in 2016." BEA Wire, March 15, 2018.

https://www.bea.gov/news/blog/2018-03-15/initial-estimates-show-digital-economyaccounted-65-percent-gdp-2016.

US Department of Justice. 2016. "Justice Department and North Carolina Sue Carolinas Healthcare System to Eliminate Unlawful Steering Restrictions." Department of Justice Office of Public Affairs. June 9. https://www.justice.gov/opa/pr/justice-department-andnorth-carolina-sue-carolinas-healthcare-system-eliminate-unlawful.

US Department of Transportation. 2017. "DOT withdraws two proposed rulemakings." News Digest - DOT 91-17. December 7. https://www.transportation.gov/briefingroom/dot9117.

US Federal Trade Commission. 2013. "Google Agrees to Change Its Business Practices to Resolve FTC Competition Concerns In the Markets for Devices Like Smart Phones, Games and Tablets, and in Online Search. January 3, 2013. https://www.ftc.gov/news-events/pressreleases/2013/01/google-agrees-change-its-business-practices-resolve-ftc.

Waldfogel, Joel. 2015. "Digitization and the Quality of New Media Products: The Case of Music." In NBER book Economic Analysis of the Digital Economy, by Shane M. Greenstein, and Catherine E. Tucker, editors Avi Goldfarb, 407 - 442. University of Chicago Press.

Weil, David. 2011. "Enforcing Labour Standards in Fissured Workplaces: The US Experience." The Economic and Labour Relations Review 22(2): 33-54.

Weiss, Leonard. 1990. Concentration and Price. Cambridge, MA: MIT Press.

Wollmann, Thomas. 2019. "Stealth Consolidation: Evidence from an Amendment to the HartScott-Rodino Act." American Economic Review: Insights, 1(1): 77-94.

Wu, Tim. 2018. The Curse of Bigness: Antitrust in the New Gilded Age. New York: Columbia Global Reports.

Yurukoglu, Ali. 2018. Discussion of The Rise of Market Power and the Macroeconomic Implications By De Loecker and Eeckhout. NBER Winter Inustrial Organization Meeting, February 9-10, 2018, Stanford, CA. 